\title{
The Concept of Distributivity In Old High German and Middle High German Texts
}

\author{
Galyna Iarmolovych \\ PhD student, German department, \\ Faculty of Romance and Germanic Philology \\ Odessa National I.I.Mechnikov University \\ Odessa, Ukraine
}

\begin{abstract}
Quantification and numbers, numerals and number words have been in the focus of research on different levels of linguistical studies. The mathematical thinking and understanding of primitive arithmetical manipulations have been covered from both the mathematical and psychological points of view. The concept of distribution developed from the ability to group objects and belongs to the second wave of the mathematical understanding of primitive people. Being one of the first concepts developed in the human consciousness it stayed un-nominalised until the development of the number consequence paradigm. The distributive constructs existing in the Modern German language are a result of development from the Proto Indo European through the Proto Germanic, Old High German, and Middle High German languages. However, the modern standard concept of distributivity is built on the preceding word - i.e., a number of colloquial variations keep being used in some German dialects.
\end{abstract}

Keywords: distributive numerals, German language history, numeral, number, linguosynergetics, selforganising systems

Quantification, numbers, and numerals as the foundational entities of mathematical thinking have raised interest among scientists in a wide range of disciplines. They have been and keep being studied from the philosophical, ethnolinguistical, historical, linguistical, anthropological, and psychological points of view. In this article the focus is on the concept of distribution, grouping and a subsection of numerals - the distributive numerals. The exemplary material used in this article, was found in the epics written in the Old High German and Middle High German languages and dictionaries of the corresponding languages.

A ,methodological revolt" - is believed to have happened in the past twenty years in language related fields of research. The focus of scientists around the world has moved from „what?“ to „how?“ and „why?“. The insatiable striving for the systematising of isolated knowledge, description, and explanation is connected to the dominant image of static and invariable systems. The appearance and development of this scientific doctrine is easy to explain: the chaotic uninterrupted stream of events/phenomena, their permanent shift and change, their evolution and diffusivity - this all demands a set of more or less steady descriptive tools. Static systems allow one to organize a variety of phenomena and to make them easier to 
observe, to perceive, and to research. Hence the static method has served linguistics well - it has created a clear, transparent system organized in a hierarchical order.

Unfortunately, the disadvantages of such a system are also well known: its passion for organizing leads to the gradual idealization and thus to the generalization of the concepts, causing the simplification of the object under study, i.e. language itself. While studying language as a dynamic system, including all its chaotic phenomena, we deal with the general problem of reality`s structure, with the possibility of revealing universal laws, by which natural and artificial language systems function. Linguists German and Pishchalnikowa support this belief „Various and multi -aspectual text studies have shown, from the psycholinguistics point of view, in the past 10-15 years, that the language is no linear sequence of language elements, but rather a complex hierarchically organized exponent of a certain nonlinear notional/conceptual entity“ $[1,11]$. The science of linguistics should equally study the isolated phenomena, the mechanisms of natural speech and the cognitive structures that an individual's intellectual activity rests upon.

Observing events and facts from the synergetics` point of view has brought humanities closer to such disparate subjects as physics and mathematics. Thus, numerous notions and terms are being effectively applied to the objects of linguistic research. The main goal of synergetics phrased by the editors of the Synergetics`Volume in the Encyclopedia of Complexity and System Science is “. ... the search for unifying principles for systems that are composed of many individual parts or components, and that may show the phenomenon of self-organization, i.e., the spontaneous formation of spatial, temporal, spatial-temporal or functional structures" $[2,6]$. The main point that linguosynergetics brings into focus in language research is that "the unity itself represents a different, independent substance, than the elements composing it, and thus the laws of building a system are substantially different from the laws of syntagmatics and paradigmatics of separate elements" $[1,12]$. It is typical for linguosynergetics to draw attention to systematic ideas and their implementation into cognition and speech-producing modelling activities [3, 232]. Keywords strongly connected with synergetics - „Attractors, chaos, bifurcations and possibly catastrophes are rigorously defined mathematical terms that can only be used metaphorically when talking about language." [4, 3] However the primary ones remain intact - its all about chance events and fluctuations. The ground ideas of synergetics are openness, nonlinear nature, dynamicity of the system. These principles, when applied to 
language research reveal new knowledge about meaning-making, the functioning of communicative processes and language training methods.

Diachronic research has a special place in linguosynergetics research. Since the selforganizing language systems are inherently dynamic, this method can be shown to be especially effective in investigating the origins of language. The works of Nettle, Livingstone, Ehala, and Hurford attempt to explain the existing language diversity and its roots, as the evolution of a single language. The questions in focus could not be answered, when investigating only from a single individual's point of view. A successful project would need a complex approach from the perspective of a language as a self-organising system with the aid of structure models and computer simulations. The most relevant subfields in linguistics are: phonological systems, the emergence of grammar, word adoption and the development of concepts. Unfortunately the lack of computer literacy among linguists prevents them from expanding computer simulations, but there is a clear point of contact with yet another remote field of knowledge.

Another difficulty on the way of a linguist researching in the field of diachronic linguosynergetics is the study material itself. Studying a language system diachronically is, basically, studying phenomena between language stages remote from each other in time (synchronic language systems) by comparing and analysing them. What distinguishes it from language history is that it focuses rather on the critical stages and the evolutionary processes that surely exist in the void between the already described synchronic reflexes of a language. The existence of only written artifacts, the fragmentary nature of the preserved material, and its thematical, dialectal, stylistic and social diversity make it hard to conduct a clean, adequate experiment. Hence, T.I.Dombrovan, sees the Bible (its asynchronical text versions) as the common point of comparison for analysing diachronic change in language structure. [5, 29] Highly equal with respect to context they perfectly illustrate the structural change, that has happened in the textual corpus.

The perception and understanding of a number by humans is one of the primary proofs of mental development. Numerous archaeological findings denote that counting and quantifiers appeared before the invention of writing. Such proofs have appeared all around the world and are present in various forms. Most often these are knots, bones, bundles, dots, cuts, stones, sticks, mussels and other objects easily found in nature. For example, a young wolf s bone, found on the territory of the modern Czech Republic in 1937, is covered in cuts of different 
length which are grouped in a certain way. [6, 9]. The analysis of these cuts and their grouping leads to the conclusion that the counting existed in this territory in the prewriting period and calls into question the widespread belief, rooted in Jakob Grimm`s theory, that it developed from the observation of the hand, fingers and fists.

A similar conclusion was made by the ethnographers working on the findings in the cave Drachenloch 2,5 kilometres up in the Alps [7, 141]. This proves the central role of bear caves in the rituals of primitive people. Stoliar describes the findings as highly systematised structures used for bear-bone storing. A part of the whole cave was separated from the rest with six stone boxes filled with a certain amount of skulls, femurs, tibia and other bigger bear`s bones. The totemic meaning of bears to the primitive people is undeniable, but another conclusion made by Stoliar is that the grouping of objects and the systematisation (circle and cross) point to an already developed understanding of distribution. This kind of grouping and distribution presumably served the purpose of keeping track of the amount of animals defeated by each warrior, defining the winner and attempting to amplify their strength. Very similar conclusions were made in other caves with a comparable distribution of objects (Baverian Petershalle, Austrian Salzofen and French Kluni) [8, 100; 7, 144].

One of the earlier methods of keeping accounting records were the so-called tally sticks. They were used on most territories that carry the burden of having a standard number system because of their primitive functioning, but they are often hard to decode due to their local usage. For example, the Han dynasty w wooden sticks with inscriptions are believed to be an intermediate stage between typical tally sticks and written numerals. This method of preserving information set roots so deep into the minds of people, that even now the Chinese write their characters vertically. The word for book in the Chinese language is a bundle of sticks Before the officiation of the Han sticks different provinces used different kinds of symbols to create a functioning accounting system, but with Han sticks it became easier to account for purchases and usage of resources. This simplification led to the appearance of distributive symbols leading to even greater simplification. $[9,168]$ It should be also mentioned, that even after the actual nominalisation of numerals and spread of Latin and Arabic number symbols this primitive method of counting was often used by illiterate people to handle business up to the beginning of the 19-th century $[8,101]$. 
Another primitive but not linear way of denoting distribution without writing are the knots. In this case the different types of knots/different colours/different materials were used to identify different numerals and the usage of several rows of knots was responsible for the multiplication of the previous rows. The knot-numerals existed for "strategic" base numbers, such as $1,2,5,10,20[9,176]$

The concept of distribution has a long history in morphological and syntactical studies, but the term "distributive numeral" was first introduced into linguistics in the dissertation of David Gil in 1982 [10]. In his thorough work he outlines the morphology, syntax and semantics bringing up examples from the Tagalog, Maricopa, Georgian, English, and German languages. He has consistently elaborated on this topic further, having finally created a page/chapter on distributive numerals on WALS (the World Atlas of Language Structures online) [11]. The page he developed maps the way distributive numerals are formed, covering a total of 251 languages and dialects. The information given on the map is a cumulative gathering of research from scientists all over the world.

The possible categories are:

- no distributive numeral at all: 62 (the languages of this category still display the concept of distributivity, they just use paraphrasing of different kind)

- marked by reduplication: 85 (this category is believed to be the oldest, most primitive one, and to have been the way numerals, at least some of them, appeared in the first place)

- $\quad$ marked by prefix: 23

- marked by suffix: 32

- $\quad$ marked by preceding word: 21

- $\quad$ marked by following word: 5

- marked by mixed or other strategies: 23

While covering Germanic languages, David Gil refers to a particularly interesting pattern displayed in Dutch, Yiddish and German [11]. On the map he separates 3 types of Yiddish (Bessarabian, Lithuanian and Polish) - with all mark distribution preceding word, 4 types of Dutch (standard, Brabantic, Limburg and Seeuws) - with no distributive numerals and 15 types of German. The latter covers dialects of Germany, Austria and Switzerland - which, 
unlike the standard language (where distribution is formed with the preceding "je"), is shifting between 'no distributive numerals` and the ones `formed with the help of a preceding word'. The German (Bavarian, Mansfeldish, Westfalian, Thuringian, Hannover, Berlin, Ripuarian) and Austrian (Upper Austrian) colloquial dialects resemble their Western counterparts in having no distributive numeral construction. Zurich, Thurgau, Ostschweiz, Bern, Appenzell - the Swiss dialects display a colloquial usage of the "je" construct. Further movement to the East brings other words into the equation of distributivity. For example, the Timisoara dialect uses "jeder" and the Lodz version of Yiddish preserves the inherited from the Middle High German "zu". Moving to the East from Lodz, one once again finds distributive numerals formed by a preceding word.

The variation of distributing structures described above leads to the immediate object of study of this article, namely the distributive constructs in Old High German and Middle High German. In the course of our research the following constructs were found:

- distribution marked by the preceding word;

- distribution marked by the following word;

- distribution marked by suffixation;

- distribution marked by mixed or other strategies;

The construct of $j e+$ cardinal numeral stem, which is common in modern German, is present in the form of $i e+$ cardinal numeral stem:

dô nam si aber Esêalt

und huop ir ie zwêne mit gewalt

über der bürge zinne.

Lanzelet, 7615 [12]

Bi handen si sich viengen, ie zwo und zwo neben ein ander giengen.

Rabenschlacht, 140 [13]

It is also present in the combination of $z e, z u, z u o$ sometimes connected with the following cardinal numeral stem in a proclitical junction (both - separated and unified versions can be found in the same text): 
Owe, do nam er Schemmingen

(do nam er schemingen $P$.)

ze beiden sporn, do liez er dar chlingen.

Rabenschlacht 393 [13]

Distribution marked by the following word appears in three variations - a numeral sequence with the stem falt (see table 1), cardinal numerals, with the stem mal (counting bases are prominent here) (see table 2), and a rare example used exclusively with the thousand with the stem stunt.

der dinge ist tûsent stunt mê,

diu lânt dir selten werden wê;

Die Klage, 687 [14]

Table 1

\begin{tabular}{|l|l|l|l|l|}
\hline & $\begin{array}{l}\text { Proto } \\
\text { Germanic }\end{array}$ & Old High German & Modern German & Modern English \\
\hline $\mathbf{2}$ & *twifaldaz & zwifalt & zweifach & twofold \\
\hline $\mathbf{3}$ & prī + -feald. & drifalt & dreifach & threefold \\
\hline $\mathbf{4}$ & *fepurfalpaz & & vierfach & fourfold \\
\hline $\mathbf{5}$ & fïf + -feald. & fiffalt & fünffach & fivefold \\
\hline$\sim$ & -faldaz-falpaz & gimanagfalton & mehrfach & manifold \\
\hline
\end{tabular}

Table 2

\begin{tabular}{|l|l|l|l|}
\hline & Middle High German & Modern German & Modern English \\
\hline 1 & Einmâl & einmal & once \\
\hline 2 & ze-mâle & zweimal & twice \\
\hline 100 & hant-mælec, hant-mâl, hunt-mâl & hundert mal & hunded times \\
\hline 1000 & dôzemale & tausend mal & thousand times \\
\hline$X$ & un-mælic & kein mal & no time (never) \\
\hline
\end{tabular}


Distribution marked by suffixation was found in the following two cases: zwiro, driror. The last example found in the Rabenschlacht is distribution marked by a pluractional verb in one manuscript and by a preposition+noun structure in the other: wider seiten - each side:

$N u$ wert iuch, wichrozzen! nu wert uch vast ir recken $P$.

Uns bestent di chuenen widersazzen.

vns besten die kunen wider seiten $P$.

Rabenschlacht 835 [13]

The latter example demands a deeper explanation of the correlation of distributive numerals with the pluractional verbs. In the Duden dictionary the distributive number word can be found under the name of „Distributivum“ with a link to „Verteilungszahlwort“ and „Distributivzahl“ as synonyms - Numerale, das die Einteilung in untereinander gleiche Mengen bezeichnet; Verteilungszahlwort, Einteilungszahl (im Deutschen durch ,je“ wiedergegeben; z. B. ,je drei“‘) [15]. A numeral that describes the division into equal quantities (Author`s translation). The function given by this description does not cover the whole concept of distributivity. The latest cross-semantic approaches describe its function as "plurality of events or individuals distributed with respect to another plurality" [16, 1] The difference between the two is that distributive numerals modify noun phrases to indicate a plurality of individuals while the pluractional morphemes modify verb phrases to indicate a plurality of events. Which means that they pertain to different syntactic categories and different semantic domains. Distributive numerals and pluractional verbs also share important compositional properties. First of all, the plurality of actions or events is described relative to another plurality referred to in context. They both act as a plurality filter and put restrictions on what may serve as a distributive key $[16,17]$. In this case the verb widerscezzen does not belong to the domain of pluractional verbs because it does not indicate the plurality of events, though it definitely indicates the opposition, thus setting a plurality filter on the amount referred to.

\section{Conclusions}

Despite certain weaknesses (non-ideal research material, lack of computational literacy) diachronical linguosynergetics complements the traditional language history research with a new perspective - studying the language as a dessipative system using new, cognitive instruments. 
The concept of distribution has developed from the grouping of objects which has developed from the need to process bigger numbers, which in its turn has developed from the primitive human ability to distinguish few from many, which is a direct result of evolution. Thus, the concept of distribution existed longer than many other quantification concepts and arithmetical operations. Nevertheless, the actual nominalisation of this group of quantifiers happened after the appearance of cardinal and ordinal numerals and is based on the usage of their stems. Its verbal realisation differs from language to language and can be grouped by the way it is marked into seven main groups.

In Old-High German as in Middle High German the concept of distributivity is formed in four ways: on a proclitic pronoun-noun bond of $z e-, z u-z u o$ - and the numerals`stem; through the suffixation $-r-$ - -ir-, -ro-; through the addition of a preceding word, $i e$; through the addition of the following words/stems: falt, mâl, stunt. The material researched for this article gave another example a contextual distribution of wider, which works only for opposing entities in one manuscript and a verb widerscezzen representing distributive plurality in the other.

The stems used in the formation of the distributive numerals are mostly the ones believed to be "bases of counting". They were at first unstable and conditioned by the local needs, later they gradually developed into stable ones, one, two, five, ten, hundred, dozen, following the laws of linguosinergetics (naturally developing ecosystems of languages).

The concept of distributivity has lately come into light, due to the numerous studies that were done on this topic, but it remains understudied in some aspects.

\section{References}

1. German I. A. Pishchalnikova V. A., 1999. Linguosynergetics. Barnaul: Altai National University. Pp.110.

2. Hutt A. Haken H., 2020. Synergetics. (Encyclopedia of Complexity and Systems Science). Stuttgart: Springer. Pp. 455.

3. Ismailova O. I., 2018. The Peculiarities of Linguistic Synergetics. Synergy of science. №25. - p. 881-884.

4. de Boer B., 2009. Self-organisation in language. Cambridge University Press. [online] Available at: https://www.cambridge.org/core/books/selforganisation-and-evolutionof-biological-and-social-systems/selforganisation-inlanguage/19F8A15FFC0A82A179F6B115BE2E3BEB.

5. Dombrovan T. I., 2014. Diachronic linguosynergetics as a new approach to the studies of language development. Writings in Romance-Germanic Philology. №2. p. 24-32. 
6. Resnikoff, H. and Wells, R., 1984. Mathematics in civilisation. New York: Dover.

7. Stoliar A.D. 1971 Natural art of neanderthals as the basis of genesis. Natural Art. Novosibirsk. p. 118-164.

8. Rybakov B.A. 1994. The paganism of the old slavs. Moscow: Nauka.

9. Menninger, K. 2013. Number Words and Number Symbols. New York: Dover Publications.

10. Gil, D., 1982. Distributive numerals. Los Angeles: University of California, Los Angeles dissertation.

11. Gil, D., 2021. WALS Online - Chapter Distributive Numerals. [online] Wals.info. Available at: <https://wals.info/chapter/54> [Accessed 2 March 2021].

12. Kragl, F. and Ulrich, 2006. Lanzelet. Berlin: Walter de Gruyter.

13. Lienert, E. and Wolter, D., 2005. Rabenschlacht. Tübingen: Max-Niemeyer Verlag.

14. von Aue, H. and Gärtner, K., 2015. Die Klage. Berlin/München/Boston: De Gruyter.

15. Duden. 2021. Verteilungszahlwort. [online] Available at: <https://www.duden.de/rechtschreibung/Verteilungszahlwort> [Accessed 3 March 2021].

16. Kuhn, J., 2019. Pluractionality and distributive numerals. Language and Linguistics Compass, 13(2), p.e12309. 